\title{
MicroRNA Based Therapy and Osteoporosis: A Review of a Novel Therapeutic Agent from Diagnosis to Treatment
}

Tina Saber ${ }^{1}$, Dhuha Saeed $\mathrm{Ali}^{2}$, Foroozandeh monem homaie ${ }^{3}$ and Reza Vazifehmand ${ }^{4^{*}}$

${ }^{1}$ Beckman Laser Institute and Medical Clinic, University of California, Irvine, Ca, USA

${ }^{2}$ Halal Products Research Institute, Universiti Putra Malaysia, Serdang, Selangor, Malaysia

${ }^{3}$ Department of Biochemistry, Science and Research University-Fars Branch-Shiraz-Iran

${ }^{4}$ Young Researchers and Elite Clubs, Islamic Azad University, Rasht Branch, Iran

\begin{abstract}
Disequilibrium between bone resorption and bone formation may cause osteoporosis that reduces bone integrity and physiological function of skeletal system. Osteoblast and osteoclast genesis are two major of biological events that act in bone turnover and dynamic rate of bone remodeling. Ample evidences have been revealed that RANK-L/ OPG, Wnt and BMP Pathways are crucial pathways involved in osteoporosis. Treatment of osteoporosis is becoming important task in post menopause women and old people. Current treatment strategies with osteoporosis drugs are mainly by inhibiting the bone-resorbtion. However, these synthetic medicines have limitless side effects. Several studies have established the important of a group of small non-coding RNAs (MiRNAs) which involve in pathogenesis osteoporosis, bone remodeling, osteoblast differentiation and osteoclast formation and has consider as a gold biomarker for osteoporosis treatment. The pathogenicity factors of osteoporosis, pathways involved in the disease and potential replacement treatment have been emphasized in this paper.
\end{abstract}

Keywords: Osteoporosis therapeutic strategy; Wnt signaling pathway; RANKL/OPG signaling pathway; BMP pathway; MiRNAs

\section{Introduction}

Osteoporosis can be defined as a disease of bone metabolism associated with low bone mass and micro-architectual deterioration, which increase the risk of bone fracture [1]. Etiologically this disease has a complex interaction between genetics and environmental factors and lifestyle with an disequilibrium between two critical biological processes namely osteoblastic bone formation and osteoclastic bone resorption [2,3]. Approximately 28 million individuals are involved and estimated 1.5 million fractures take place annually in United States [4]. Disease is categorized as primary, which is closely correlated with age and sex, and secondary, that occurs at any age which effecting men and women equally. At the molecular level, three critical pathways including Wnt Pathway, BMP Pathway and RANK-L/OPG Pathway are involved in osteoporosis and bone remodeling process. Osteoporosis basing to be a serious public health issue especially for these two groups of population, rarely elderly and post-menopausal osteoporosis women [4]. Although drug selection for osteoporosis is limited but evidence has demonstrated the crucial role of MiRNAs in osteoporosis treatment [5]. This review highlighted the pathogenesis of osteoporosis, molecular mechanisms involved in the disease and comprehensive review of osteoporosis treatment using chemical drugs and MiRNAs therapy as a potential novel therapeutic agent in osteoporosis.

\section{Literature Review}

\section{Pathogenesis of osteoporosis}

Osteoblastogenesis and impact osteoclastogenesis are two crucial biological events of bone turnover which can reflect the dynamic rate of bone remodeling [6,7]. Cumulating evidence suggested that three major molecular pathways including RANK-L/OPG Pathway, Wnt Pathway and BMP Pathway are involved in pathogenesis of osteoporosis.

\section{Receptor activator of NF-kB ligand- osteoprotegerin (RANKL-OPG Pathway)}

Various factors, receptor activator of NF-kB ligand (RANKL) and macrophage colony stimulating factor (M-CSF), are secreted from osteoblasts. These factors perform like a regulator in the process of differentiation of osteoclast progenitors to mature osteoclast. The cells are detected by expression of various markers such as calcitonin receptor [8-11], and alpha $v$ beta 3 integrin chain $(\alpha v \beta 3)$ [12]. The process has activates various signaling pathways such as NF-kB with the involvement of RANK and RANKL, Many signaling pathways could be activated during the regulation of osteoclastogenesis, such as NF-kB, via binding of RANK and RANKL, important regulator of osteoclast precursors along with $\mathrm{CD} 1 \mathrm{~b}, \mathrm{CD} 14$ and $\mathrm{cFms}[13,14]$. Inhibition of osteoclastogenesis occurs when Osteoprotegerin (OPG), a decoy protein secreted by osteoblasts, could bind to RANKL and RANK. Involvement of RANKL-OPG play a crucial role in the cross-talk between osteoblast-mediated bone formation and osteoclast-mediated bone resorption $[13,14]$.

\section{Wnt signaling pathway}

Wnt pathway consists of several signaling proteins that have critical role in multiple biological processess such as cell survival, migration, apoptosis, cell proliferation and differentiation [15] that is involved in bone homeostasis, bone remodeling process and proliferation and differentiation of osteoblast progenitors [16-18]. Osteoblasts formation and bone-resorbing osteoclast are terminally differentiated cells with short lives. Therefore, replacement of both with a new ones from mesenchymal and hematopoietic stem cells are necessary $[19,20]$. Wnt/ $\beta$-catenin also known as canonical wnt signaling pathway. It generates osteoblasts through the promotion of differentiation to osteoblast lineage from pluripotential mesenchymal stem cell [21]. In response to the pathway, cell expressed with osterix-1 (OSX1)

*Corresponding author: Vazifehmand R, Young Researchers and Elite Clubs Islamic Azad University, Rasht Branch, Iran, Tel: +0060122124389; E-mail: Vazifehmand@gmail.com

Received May 08, 2018; Accepted May 23, 2018; Published May 25, 2018

Citation: Saber T, Ali DS, Homaie FM, Vazifehmand R (2018) MicroRNA Based Therapy and Osteoporosis: A Review of a Novel Therapeutic Agent from Diagnosis to Treatment. J Spine 7: 416. doi: 10.4172/2165-7939.1000416

Copyright: @ 2018 Saber T, et al. This is an open-access article distributed under the terms of the Creative Commons Attribution License, which permits unrestricted use, distribution, and reproduction in any medium, provided the original author and source are credited. 
develops to osteoblast. The life span of mature osteoclasts increases by prevention of the apoptosis process in both $\beta$-catenin dependent and independent pathways [22]. On the other hand, wnt/ $\beta$-catenin signaling able to decrease differentiation of osteoblast through encouragement of production and secretion of osteoprotegenin (OPG). OPG is a natural antagonist of RANKL [23]. It should be noticed that RANKL which is produced by primarily osteocytes is essential for the differentiation, survival and function of osteoblast and bone resorption [24]. In osteoclast production, bone marrow macrophages (BMMs) are differentiating into positive pre-osteoclasts and tartarate-resistant acid phosphatase (TRAP). These compounds are crucial in forming the mature osteoclast [25]. Wnt signaling has effect on the inhibiting of osteoclast activity by extracting Frizzled-related protein 1 (Sfrp1). As Sfrp1 is a binding site of Frizzled protein, it binds to RANKL competitively. This complex down-regulates the bone resorption $[26,27]$ and decrease the level of $\beta$-catenin in osteoblast progenitors, hence caused the bone loss [28].

\section{BMP pathways}

A group of cytokines known as Bone morphogenetic proteins (BMPs), belong to transforming growth factor- $\beta$ (TGF- $\beta$ ) superfamily. BMP is managed by RSmads and Co-Smad. The interaction of BMPs and responsive receptors influences the phosphorylation of Smads, thus enhance osteogenesis [29,30]. During this process, Runx2, a transcription factor connects many signal transductions in bone remodeling and osteoclast differentiation activated and regulates the genes associated to bone formation. It is necessary for activation of Smads by BMPs as well [31]. Ample evidence revealed that Runx2 enhances the level of PI3K/ Akt [32]. During osteoblast differentiation, another mediator molecule known as osterix. This molecule act as a mediator for Runx2 that play an important role in managing bone formation and bone resorption [33]. Several successful project implementations involving of HDAC family members in bone remodeling including HDAC1 and HDAC3 (mostly found in bone tissues) [34,35].

\section{Current treatment of osteoporosis}

Currently, there is a limitation of drug selection for osteoporosis treatment. Those problems are due to various potential and toxicity issues. Thus, establishing a new approach for osteoporosis has become a great interest. A current treatment, Calcitonin, was related to cancer for long-term users, thus was eliminated as one of the treatment cycle in the Europe countries [36]. It leave Teriparatide (PTH 1-34) and PTH 1-84 (stimulate the formation of new bone), and Biphosphonates (antiresoprption) as the remaining choices [37].

\section{Anabolic agents in osteoporosis treatment}

Anabolic agents are a class of osteoporosis treatment drug with many kinds of therapeutic targets that increase bone mass by directly stimulating new bone formation [38-48].

Parathyroid hormone (PTH) analogs: Human recombinant PTH is the only anabolic therapy that permitted to treat osteoporosis, such as PTH1-34 and PTH1-48 [49]. The most common side effects of PTH analogs are mild asymptomatic hypercalcamia and hypercalciuria whereas PTH-related protein cause hypercalcemia in malignant patients [49]. The main limitation for these kinds of drugs is the economic factor because PTH analogs are expensive to produce.

Potential therapeutic targets of osteoporosis: Having knowledge of the micro environmental control process that able to regulate bone modeling and bone remodeling is necessary in planning therapeutic for prevention and treatment of bone fragility. Resorption inhibitors are new class of osteoporosis treatment agents that are being developed based on their action mechanisms. ODN, DPH, GSK-3 inhibitor and DDK-1 inhibitor are examples of this new class of drugs for osteoporosis treatment [49].

\section{Cathepsin K inhibitors}

Cathepsin K inhibitors, such as Odanacatib (ODN), are antiresorptive agents $[38,39]$ that digest the type I collagen in resorption pits. They targeting the selective osteoclast digestive enzymes making their anti-resorptive effect are tolerable compare to more potent antiresorptive agents [40-42]. ODN has intermediate effect observed on continuous bone resorption and transient down regulate in bone formation [40-42]. Another experiment was done by a group of researchers that revealed cathepsin $\mathrm{K}$ deficiency led to maintenance of, or an increase, in bone formation in mice, rabbits and monkeys $[43,44]$. Odanacatib is undergoing phase III clinical trials in postmenopausal women and older men. Another example, ONO-5334, acts in suppressing the bone resorption is experiencing Phase I and II clinical trials [45]. Although, such these inhibitors have a successful clinical trials but most of them express multiple kinds of side effects [45].

\section{Inhibition of DDK-1(Dikkoff-1)}

The inhibition of canonical Wnt signaling pathway take places by producing a trinary complex between LRP5, DKK-1 and DKK receptor. This kind of interaction encourages the fast internalization and reduction of LPR5 (low density lipoprotein receptor-related protein 5). Later, it causes the inhibition of Wnt [46]. Contradiction to that, inhibition of the DKK-1 and LRP5 activates the Wnt signaling. In a study have been shown that using of anti-DKK-1 antibodies trigger increase number of osteoblasts and down regulate the number of osteoclasts [47]. This study was performed on a mouse model subjected with multiple myeloma.

\section{Wnt/ $\beta$ catenin signaling pathway activators and inhibitors in osteoporosis}

Binding of Wnt to the receptor and LPR5/6 in osteoclasts prevent the formation of GSK-3 (intracellular glycogen synthase kinase-3) in Wnt signaling pathway [22]. This inhibition of the signaling increases the level GSK3 that can inhibit the breakdown of catenin. This mechanism causes transcriptional co-activation of genes integral to bone formation [22]. Most of the bone active drugs mainly target at Wnt signaling pathway, which includes Wnt antagonist inhibition like sclerostin, DDK1 and SFRP1, along with neutralization of antibodies and suppression of glycogen synthase kinase $3 \beta$ (GSK3 $\beta$ ) which promotes phosphorylation and degradation of $B$-actin [48]. Number of endogenous antagonists constrains the $\mathrm{Wnt} / \beta$-catenin pathway, namely Wnt-inhibitory factor and members of the secreted frizzled-related protein family. These endogenous antagonists inhibit the Wnt $/ \beta$-catenin pathway and later cause the down-regulation of bone formation. Same reaction occurs for LRP5/6 inhibitors that block this signalling [48].

\section{Osteoporosis linked MicroRNAs (MiRNAs)}

MiRNAs able to control gene expression at the post-transcriptional level by targeting the 3' un-translated region of mRNA [50]. They have ability to regulatevarious biological pathwayincluding cells development, hematopoiesis, pathophysiological process, organogenesis, apoptosis, cell differentiation and tumor genesis [51]. Various studies indicated that MiRNAs regulate osteoclastogenesis and are involved during the pathogenesis of osteoporosis as well [52]. Most of the MiRNAs control the proliferation and differentiation of osteoblast. Some of MiRNAs play a crucial role in controlling the differentiation of osteoclast [53]. On the basis of previous investigation, aberrant MiRNAs expression 
Citation: Saber T, Ali DS, Homaie FM, Vazifehmand R (2018) MicroRNA Based Therapy and Osteoporosis: A Review of a Novel Therapeutic Agent from Diagnosis to Treatment. J Spine 7: 416. doi: 10.4172/2165-7939.1000416

Page 3 of 5

revealed a close association with osteoporosis, for example, miR-2861 as a novel MiRNAs able to target histone deacetylase 5(HDAC5), a negative regulator of RUNX2, can cause familial osteoporosis [54]. Polymorphisms in miR-146a and miR-14b target sites (able to target FGF2) are significantly associated with femoral neck bone mineral density [55]. Table 1 shows a brief history of MiRNAs functions and their targets in osteoporosis [54-86].

\section{Discussion and Conclusion}

In recent years, osteoporosis becoming a serious public health problem in post-menopausal osteoporosis women and old population. Despite of an increasing number of advanced researches performed to gain better understanding of the pathogenesis and molecular pathways involved in osteoporosis grey zone is still exist in the knowledge of osteoporosis association with variety of molecular mechanisms. Recent approaches in managing osteoporosis are mainly focused on the bone-

\begin{tabular}{|c|c|c|c|}
\hline MicroRNAs & Target gene(s) & MicroRNA Function & References \\
\hline $\mathrm{miR}-2861$ & HDAC5 & Promotes osteoclast differentiation and primary osteoporosis induction & {$[54,56]$} \\
\hline $\operatorname{miR}-3960$ & HOXa2 & $\begin{array}{c}\text { A repressor of RUNX2 and acts as a regulatory role in osteoblast } \\
\text { differentiation }\end{array}$ & [57] \\
\hline miR-223 & Ago2, DGGR8, NFI-A, RANKL, TNF- $\alpha$ & $\begin{array}{l}\text { Inhibit of osteoclast marker and transcription factor expression, } \\
\text { decrease osteoclastogenesis (decrease bone resorption)-considered } \\
\text { as a therapeutic target for a range of bone metabolic disorders }\end{array}$ & [58] \\
\hline miR-206 & Cx43 (Connexin43) & Induction of osteoblast differentiation & {$[59]$} \\
\hline $\begin{array}{l}\operatorname{miR}-29 \\
\operatorname{miR}-27 \\
\text { mir-335-5P }\end{array}$ & $\begin{array}{l}\text { Wnt -Signaling pathway } \\
\text { (DDK1, Kremen2, SFRP) }\end{array}$ & $\begin{array}{l}\text { Up regulated, regulate osteoblast differentiation by suppresses of key } \\
\text { wnt signaling antagonists }\end{array}$ & {$[60,61]$} \\
\hline $\operatorname{miR}-21$ & PDCD4, c-Fos & Down regulation of programmed cell death- 4 & {$[58,62]$} \\
\hline $\begin{array}{l}\operatorname{miR}-93 \\
\mathrm{miR}-96\end{array}$ & $\begin{array}{l}\text { SP7 transcription factor } 7 \\
\text { Zfp521 }\end{array}$ & $\begin{array}{c}\text { Regulatory role in stem cell and bone marrow mesenchymal stem cell } \\
\text { differentiation }\end{array}$ & {$[63,64]$} \\
\hline $\begin{array}{l}\text { miR-199a } \\
\text { miR-26a }\end{array}$ & SMAD1 & Regulatory role in skeletogenesis and its pathogenesis & [65] \\
\hline miR-126 & VCAM1, HOXA9, & Regulatory role in skeletogenesis and its pathogenesis & [66] \\
\hline miR-140 & HDAC4 & Regulatory role in skeletogenesis and its pathogenesis & [67] \\
\hline $\operatorname{miR}-125 b$ & ERBB2 & $\begin{array}{l}\text { Regulatory role in skeletogenesis and its pathogenesis, considered as } \\
\text { a potential non- invasive biomarker for postmenopausal osteoporosis }\end{array}$ & [67] \\
\hline $\begin{array}{c}\text { miR-29b } \\
\text { miR-133a, mir-135b }\end{array}$ & $\begin{array}{c}\text { HDAC4, TGF } 33 \text {, ACVR2A, CTNNBIPI, DUSP } \\
\text { RUNX2, SMAD5 }\end{array}$ & Skeletogenesis development & [68] \\
\hline $\begin{array}{l}\operatorname{miR}-638 \\
\operatorname{miR}-663\end{array}$ & JUN, FOSB, SP3, MYC & Regulate osteoblastogenesis & [69] \\
\hline miR-29b & $\begin{array}{l}\text { MMP2, c-Fos, HDAC4, TGF } 33 \text {, ACVR2A, } \\
\text { CTNNB1P1and DUSP }\end{array}$ & $\begin{array}{c}\text { Down regulated in RNKL induced osteoclastogenesis that inhibits } \\
\text { osteoclast differentiation }\end{array}$ & [70] \\
\hline $\begin{array}{l}\operatorname{miR}-378 \\
\mathrm{miR}-146 a\end{array}$ & NFIA & $\begin{array}{c}\text { Down regulated in osteoclast differentiation that able to inhibits } \\
\text { differentiation }\end{array}$ & [71] \\
\hline $\operatorname{miR}-133 a$ & CXCL11, CXCR3, SLC39A1 & $\begin{array}{l}\text { Up-Regulated in post-menopausal osteoporosis, Its overexpression } \\
\text { (targeting SLC39A1) is negatively correlated to osteogenic } \\
\text { differentiation of hMSCs }\end{array}$ & [72] \\
\hline miR-338-3P & RANKL & Induction of osteoblast & [73] \\
\hline MiR-21 & RANKL & Induce osteoclastogenesis & [74] \\
\hline miR-503 & RANKL & $\begin{array}{l}\text { Inhibits RANKL-induced osteoclast differentiation in post-menopausal } \\
\text { osteoporosis women }\end{array}$ & [75] \\
\hline miR-150-3P & $\beta$-catenin & $\begin{array}{l}\text { Suppresing of osteogenic differentiation through downregulation of } \\
\qquad \beta \text {-catenin }\end{array}$ & [76] \\
\hline $\operatorname{miR}-125 a$ & TRAF6 & $\begin{array}{l}\text { Down regulated and Inhibits osteoclastogenesis and involve in } \\
\text { metabolic disorders }\end{array}$ & {$[77,78]$} \\
\hline $\operatorname{miR}-221$ & RUNX2 & Osteoclast differentiation & [79] \\
\hline $\begin{array}{l}\operatorname{miR}-125 b \\
\operatorname{miR}-30\end{array}$ & $\begin{array}{c}\text { ERBB2 } \\
\text { SMAD1 and RUNX2 }\end{array}$ & $\begin{array}{c}\text { Unregulated in postmenopausal osteoporosis women, as a potential } \\
\text { biomarker } \\
\text { Unregulated in postmenopausal osteoporosis women }\end{array}$ & {$[80]$} \\
\hline miR-34C & LGR4 & Promote osteoclast differentiation & [81] \\
\hline $\begin{array}{l}\operatorname{miR}-705 \\
\operatorname{miR}-3077-5 P\end{array}$ & $\begin{array}{l}\text { HOXA10 } \\
\text { RUNX2 }\end{array}$ & $\begin{array}{c}\text { Inhibit mesenchymal stem cells (MSCs) osteoblast differentiation and } \\
\text { promote adipocyte differentiation }\end{array}$ & [82] \\
\hline MiR-133b & RUNX2, ALP, OCN (osteocalcin) & $\begin{array}{c}\text { Negatively regulates the proliferation and osteogenic differentiation of } \\
\text { bone marrow mesenchymal stem cell }\end{array}$ & [83] \\
\hline $\begin{array}{l}\operatorname{miR}-148 a \\
\operatorname{miR}-422 a\end{array}$ & $\begin{array}{c}\text { MAFB } \\
\text { TOB2, PAG1, IGF1, CD226 }\end{array}$ & $\begin{array}{l}\text { Unregulated during osteoclast differentiation and promote } \\
\text { osteoclastogenesis }\end{array}$ & {$[78,84]$} \\
\hline $\begin{array}{l}\text { miR-146a, } \\
\text { miR-146b }\end{array}$ & FGF2 & Femoral neck bone mineral density, aberrant miR Expression & [80-82] \\
\hline miR-9 & AMPK Signaling pathway & Regulation of osteoblast differentiation and angiogenesis & [83] \\
\hline miR-7b & DC-STAMP & Osteoclast differentiation by suppressing NFATC1 and C-Fos signaling & [84] \\
\hline miR-106b & RANKL & Inhibits osteoclastogenesis and osteolysis & {$[85,86]$} \\
\hline
\end{tabular}

Table 1: MiRNAs involved in osteoporosis pathogenicity, osteoblast formation and osteoclast differentiation. 
Citation: Saber T, Ali DS, Homaie FM, Vazifehmand R (2018) MicroRNA Based Therapy and Osteoporosis: A Review of a Novel Therapeutic Agent from Diagnosis to Treatment. J Spine 7: 416. doi: 10.4172/2165-7939.1000416

Page 4 of 5

resorbing drugs accompanied with limitless adverse effects. Although, osteoporosis treatment based MiRNAs is becoming excellent options, but further investigation into MiRNAs role especially in controlling the differentiation of osteoclast need to be considered.

\section{References}

1. Kanis JA, McCloskey EV, Johansson H, Cooper C, Rizzoli R, et al. (2013) European guidance for the diagnosis and management of osteoporosis in postmenopausal women. Osteoporos Int 24: 23-57.

2. Boyle WJ, Simonet WS, Lacey DL (2003) Osteoclast differentiation and activation. Nature 423: 337-342.

3. Ralston SH, Uitterlinden AG (2010) Genetics of osteoporosis. Endocr Rev 31 : 629-662.

4. Cooper C, Cole ZA, Holroyd CR, Earl SC, Harvey NC, et al. (2011) Secular trends in the incidence of hip and other osteoporotic fractures. Osteoporos Int 22: $1277-1288$

5. Karsenty G, Wagner EF (2002) Reaching a genetic and molecular understanding of skeletal development. Dev Cell 2: 389-406.

6. Garnero P (2008) Biomarkers for osteoporosis management: Utility in diagnosis, fracture risk prediction and therapy. Mol Diagn Ther 12: 157-170.

7. Swaminathan R (2001) Biochemical markers of bone turnover. Clin Chim Acta 313: $95-105$

8. Granholm S, Lundberg P, Lerner UH (2008) Expression of the calcitonin receptor, calcitonin receptor-like receptor, and receptor activity modifying proteins during osteoclast differentiation. J Cell Biochem 104: 920-933.

9. Hayman AR (2008) Tartrate-resistant acid phosphatase (TRAP) and the osteoclast/immune cell dichotomy. Autoimmunity $41: 218-223$.

10. Ljusberg J, Wang $Y$, Lång $P$, Norgård M, Dodds R, et al. (2005) Proteolytic excision of a repressive loop domain in tartrate-resistant acid phosphatase by cathepsin K in osteoclasts. J Biol Chem 280: 28370-28381.

11. Ishibashi O, Niwa S, Kadoyama K, Inui T (2006) MMP-9 antisense oligodeoxynucleotide exerts an inhibitory effect on osteoclastic bone resorption by suppressing cell migration. Life Sci 79: 1657-1660.

12. Takayama S, Ishii S, Ikeda T, Masamura S, Doi M, et al. (2005) The relationship between bone metastasis from human breast cancer and integrin avB3 expression. Anticancer Res 25: 79-83.

13. Weitzmann MN (2013) The role of inflammatory cytokines, the RANKL/OPG axis, and the immunoskeletal interface in physiological bone turnover and osteoporosis. Scientifica 20: 29 .

14. Yamashita T, Yao Z, Li F, Zhang Q, Badell IR, et al. (2007) NF-kB p50 and p52 regulate receptor activator of NF-KB ligand (RANKL) and tumor necrosis factorinduced osteoclast precursor differentiation by activating c-Fos and NFATc1. J Biol Chem 282: 18245-18253.

15. Kikuchi A, Yamamoto $H$, Sato $A$ (2009) Selective activation mechanisms of Wnt signaling pathways. Trends Cell Biol 19: 119-129.

16. Hartgers FC, Looman MW, Van der Woning B, Merkx GF, Figdor CG, et al (2001) Genomic organization, chromosomal localization, and 5' upstream region of the human DCSTAMP gene. Immunogenetics 53: 145-149.

17. Hartgers FC, Vissers JL, Looman MW, Van Zoelen C, Huffine C, et al (2000) DCSTAMP, a novel multimembrane-spanning molecule preferentially expressed by dendritic cells. Eur J Immunol 30: 35853590.

18. Kukita T, Wada N, Kukita A, Kakimoto T, Sandra F, et al. (2004) RANKL-induced DCSTAMP is essential for osteoclastogenesis. J Exp Med 200: 941-946.

19. Long F (2012) Building strong bones: Molecular regulation of the osteoblast lineage. Nat Rev Mol Cell Biol 13: 27-38.

20. Teitelbaum SL, Ross FP (2003) Genetic regulation of osteoclast development and function. Nat Rev Genet 4: 638-649.

21. Rodda SJ, McMahon AP (2006) Distinct roles for Hedgehog and canonical Wnt signaling in specification, differentiation and maintenance of osteoblast progenitors. Development 133: 3231-3244.

22. Almeida M, Han L, Bellido T, Manolagas SC, Kousteni S (2005) Wnt proteins prevent apoptosis of both uncommitted osteoblast progenitors and differentiated osteoblasts by beta-catenin-dependent and -independent signaling cascades involving Src/ERK and phosphatidylinositol 3-kinase/AKT. J Biol Chem 280: 41342-41351.

23. Glass DA, Bialek P, Ahn JD, Starbuck M, Patel MS, et al. (2005) Canonical Wnt signaling in differentiated osteoblasts controls osteoclast differentiation. Dev Cell 8: 751-764.

24. Xiong J, Onal M, Jilka RL, Weinstein RS, Manolagas SC, et al. (2011) Matrix embedded cells control osteoclast formation. Nat Med 17: 1235-12341.

25. Almeida M, Han L, Martin-Millan M, Plotkin LI, Stewart SA, et al. (2007) Skeleta involution by age-associated oxidative stress and its acceleration by loss of sex steroids. J Biol Chem 282: 27285-27297.

26. Van der Horst A, Burgering BM (2007) Stressing the role of FoxO proteins in lifespan and disease. Nat Rev Mol Cell Biol 8: 440-450.

27. Salih DA, Brunet A (2008) FoxO transcription factors in the maintenance of cellular homeostasis during aging. Curr Opin Cell Biol 20: 126-136.

28. Jin Z, Wei W, Huynh H, Wan Y (2015) HDAC9 inhibits osteoclastogenesis via mutual suppression of PPAR $\square / R A N K L$ signaling. Mol Endocrinol 29: 730-738.

29. Farshdousti Hagh M, Noruzinia M, Mortazavi $Y$, Soleimani M, Kaviani S, et al. (2015) Different methylation patterns of RUNX2, OSX, DLX5 and BSP in osteoblastic differentiation of mesenchymal stem cells. Cell J 17: 71-82.

30. Ho MH, Yao CJ, Liao MH, Lin Pl, Liu SH, et al. (2015) Chitosan nanofiber scaffold improves bone healing via stimulating trabecular bone production due to upregulation of the Runx2/osteocalcin/alkaline phosphatase signaling pathway. Int J Nanomedicine 10: 5941-5954.

31. Xi JC, Zang HY, Guo LX, Xue HB, Liu XD et al. (2015) The PI3K/AKT cell signaling pathway is involved in regulation of osteoporosis. J Recept Signal Transduct Res 35: 640-645.

32. Matsubara T, Kida K, Yamaguchi A, Hata K, Ichida F, et al. (2008) BMP2 regulates osterix through Msx2 and Runx2 during osteoblast differentiation. J Biol Chem 283: 29119-29125.

33. Guo H, Friedman AD (2011) Phosphorylation of RUNX1 by cyclin-dependen kinase reduces direct interaction with HDAC1 and HDAC3. J Biol Chem 286 208-215.

34. Jeon EJ, Lee KY, Choi NS, Lee MH, Kim HN, et al. (2006) Bone morphogenetic protein-2 stimulates Runx2 acetylation. J Biol Chem 281: 16502-16511.

35. Iñiguez-Ariza NM, Clarke BL (2015) Bone biology, signaling pathways, and therapeutic targets for osteoporosis. Maturitas. 82: 245-255.

36. Ji X, Chen X, Yu X (2016) MiRNAs in osteoclastogenesis and function: Potentia therapeutic targets for osteoporosisInt. J Mol Sci 17: 349

37. Boonen S, Rosenberg E, Claessens F, Vanderschueren D, Papapoulos S (2012) Inhibition of cathepsin K for treatment of osteoporosis. Curr Osteop Rep 10: $73-79$.

38. Costa AG, Cusano NE, Silva BC, Cremers S, Bilezikian JP (2011) Cathepsin $\mathrm{K}$ : Its skeletal actions and role as a therapeutic target in osteoporosis. Nat Rev Rheumatol 7: 447-456.

39. Eisman JA, Bone HG, Hosking DJ, McClung MR, Reid IR, et al. (2011) Odanacatib in the treatment of postmenopausal women with low bone mineral density: three-year continued therapy and resolution of effect. J Bone Miner Res 26: 242-251.

40. Bone HG, McClung MR, Roux C, Recker RR, Eisman JA, et al. (2010) Odanacatib, a cathepsin-K inhibitor for osteoporosis: a two-year study in postmenopausal women with low bone density. J Bone Miner Res 25: 937-947.

41. Stoch SA, Zajic S, Stone J, Miller DL, Van Dyck K, et al. (2009) Effect of the cathepsin $\mathrm{K}$ inhibitor odanacatib on bone resorption biomarkers in healthy postmenopausal women: Two doubleblind, randomized, placebo-controlled phase I studies. Clin Pharmacol Ther 86: 175-182.

42. Cusick T, Chen CM, Pennypacker BL, Pickarski M, Kimmel DB, et al. (2012) Odanacatib treatment increases hip bone mass and cortical thickness by preserving endocortical bone formation and stimulating periosteal bone formation in the ovariectomized adult rhesus monkey. J Bone Miner Res 27 524-537.

43. Masarachia PJ, Pennypacker BL, Pickarski M, Scott KR, Wesolowski GA, et al. (2012) Odanacatib reduces bone turnover and increases bone mass in the lumbar spine of skeletally mature ovariectomized rhesus monkeys. J Bone Miner Res 27: 509-523.

44. Nagase S, Ohyama M, Hashimoto Y, Small M, Kuwayama T, et al. (2012) 
Citation: Saber T, Ali DS, Homaie FM, Vazifehmand R (2018) MicroRNA Based Therapy and Osteoporosis: A Review of a Novel Therapeutic Agent from Diagnosis to Treatment. J Spine 7: 416. doi: 10.4172/2165-7939.1000416

Pharmacodynamic effects on biochemical markers of bone turnover and pharmacokinetics of the cathepsin $\mathrm{K}$ inhibitor, ONO-5334, in an ascending multiple-dose, phase 1 study. J Clin Pharmacol 52: 306-318.

45. Morvan F, Boulukos K, Clement-Lacroix P, Roman S, SucRoyer I, et al. (2006) Deletion of a single allele of the Dkk1 gene leads to an increase in bone formation and bone mass. J Bone Miner Res 21: 934-945.

46. Yaccoby S, Ling W, Zhan F, Walker R, Barlogie B, et al. (2007) Antibody-based inhibition of DKK1 suppresses tumorinduced bone resorption and multiple myeloma growth in vivo. Blood 109: 2106-2111.

47. Carbonare LD, Giannini S (2004) Bone microarchitecture as an important determinant of bone strength. J Endocrinol Invest 27: 99-105.

48. Kanis JA (2002) Diagnosis of osteoporosis and assessment of fracture risk. Lancet 359: 1929-1936.

49. Ng KW, Martin TJ (2014) New therapeutics for osteoporosis. Curr Opin Pharmacol 16: 58-63

50. Tondravi MM, McKercher SR, Anderson K, Erdmann JM, Quiroz M, et al. (1997) Osteopetrosis in mice lacking haematopoietic transcription factor PU.1. Nature 386: 81-84.

51. Kim VN (2005) MicroRNA biogenesis: Coordinated cropping and dicing. Nat Rev Mol Cell Biol 6: 376-385.

52. Ma Y, Shan Z, Ma J, Wang Q, Chu J, et al. (2016) Validation of downregulated MiRNAs during osteoclast formation and osteoporosis progression. Mol Med Rep 13: 2273-2280.

53. Xia Z, Chen C, Chen P, Xie H, Luo X (2011) MicroRNAs and their roles in osteoclast differentiation. Front Med 5: 414-419.

54. Li H, Xie H, Liu W, Hu R, Huang B, et al. (2009) A novel microRNA targeting HDAC5 regulates osteoblast differentiation in mice and contributes to primary osteoporosis in humans. J Clin Invest 119: 3666-3677.

55. Lei SF, Papasian CJ, Deng HW (2011) Polymorphisms in predicted miRNA binding sites and osteoporosis. J Bone Miner Res 26: 72-78.

56. Li Z, Hassan MQ, Jafferji M, Aqeilan RI, Garzon R, et al. (2009) Biologica functions of miR-29b contributes to positive regulation of osteoblast differentiation. J Biol Chem 284: 15676-15684.

57. Hu R, Liu W, Li H, Yang L, Chen C, et al. (2011) A Runx2/miR-3960/miR-2861 regulatory feedback loop during mouse osteoblast differentiation. J Biol Chem 286: $12328-12339$

58. Sugatani T, Hruska KA (2007) MicroRNA-223 is a key factor in osteoclast differentiation. J Cell Biochem 101: 996-999.

59. Shibuya H, Nakasa T, Adachi N, Nagata Y, Ishikawa M, et al. (2012) Overexpression of microRNA-223 in rheumatoid arthritis synovium controls osteoclast differentiation. Mod Rheumatol 23: 674-685.

60. Kapinas K, Kessler C, Ricks T, Gronowicz G, Delany AM (2010) miR-29 modulates Wnt signaling in human osteoblasts through a positive feedback loop. J Biol Chem 285: 25221-25231.

61. Kapinas K, Kessler CB, Delany AM (2009) miR-29 suppression of osteonectin in osteoblasts: regulation during differentiation and by canonical Wnt signaling. J Cell Biochem 108: 216-224.

62. Wang T, Xu Z (2010) miR-27 promotes osteoblast differentiation by modulating Wnt signaling. Biochem Biophys Res Commun 402: 186-189.

63. Zhang J, Tu Q, Bonewald LF, He X, Stein G, et al. (2011) Effects of miR-335$5 p$ in modulating osteogenic differentiation by specifically down-regulating Wnt antagonist DKK1. J Bone Miner Res 26: 1953-1963.

64. Sugatani T, Vacher J, Hruska KA (2011) A microRNA expression signature of osteoclastogenesis. Blood 117: 3648-3657.

65. Yang L, Cheng P, Chen C, He HB, Xie GQ, et al. (2012) miR-93/Sp7 function loop mediates osteoblast mineralization. J Bone Miner Res 27: 1598-1606.
66. Han R, Kan Q, Sun Y, Wang S, Zhang G, et al. (2012) MiR-9 promotes the neural differentiation of mouse bone marrow mesenchymal stem cells via targeting zinc finger protein 521. Neurosci Lett 515: 147-152.

67. Lin C J, Liu CJ (2009) MicroRNAs in Skeletogenesis. Front Biosci (Landmark Ed) 14: $2757-2764$

68. Gordeladze JO, Djouad F, Brondello JM, Noël D, Duroux-Richard I, et al. (2009) Concerted stimuli regulating osteo-chondral differentiation from stem cells: phenotype acquisition regulated by microRNAs. Acta Pharmacol Sin 30: 13691384.

69. Rossi M, Pitari MR, Amodio N, Di Martino MT, Conforti F, et al. (2013) miR$29 \mathrm{~b}$ negatively regulates human osteoclastic cell differentiation and function: implications for the treatment of multiple myeloma related bone disease $\mathrm{J}$ Cell Phys 228:1506-1515.

70. Shibuya H, Nakasa T, Adachi N, Nagata Y, Ishikawa M, et al. (2013) Overexpression of microRNA-223 in rheumatoid arthritis synovium controls osteoclast differentiation. Mod Rheumatol 23: 674-685.

71. Wang Y, Li L, Moore BT, Peng XH, Fang X, et al. (2012) MiR-133a in human circulating monocytes: a potential biomarker associated with postmenopausal osteoporosis. PloS One 7: e34641.

72. Zhang XH, Geng GL, Su B, Liang CP, Wang F, et al. (2016) MicroRNA-338-3p inhibits glucocorticoidinduced osteoclast formation through RANKL targeting. Genet Mol Res 15

73. Chen C, Cheng P, Xie H, Zhou HD, Wu XP, et al. (2014) MiR-503 regulates osteoclastogenesis via targeting RANK. J Bone Miner Res 29: 338-347.

74. Wang N, Zubin Z, Tianyi W, Wei L, Peipei Y, et al. (2017) TNF- $\alpha$-induced NF-kB activation upregulates microRNA-150-3p and inhibits osteogenesis of mesenchymeal stem cells by targeting b-catenin. Open Bio 6: 150258 .

75. Cheng P, Chen C, He HB, Hu R, Zhou H, et al. (2013) miR-148a regulates osteoclastogenesis by targeting $\mathrm{V}$-maf musculoaponeurotic fibrosarcoma oncogene homolog B. J BoneMiner Res 28: 1180-1190.

76. Guo LJ, Liao L, Yang L, LiY, Jiang TJ (2014) MiR-125a TNF receptor-associated factor 6 to inhibit osteoclastogenesis. Exp Cell Res 321: 142-152.

77. Mengge S, Xiaoya Z, Lili C, Shishu H, Victor L, et al. (2016) The Regulatory Roles of MicroRNAs in Bone Remodeling and Perspectives as Biomarkers in Osteoporosis. Bio Med Res Int 11.

78. Hua C Honghui J, Dan C, Hao X, Keliang Z, et al. (2017) Evaluation of MicroRNA $125 \mathrm{~b}$ as a potential biomarker for postmenopausal osteoporosis. Trop J Pharm Res. 16: 641-664

79. Fei C, Na Wu, Xiaoning T, Jinzhu F, Jian L, et al. (2017) MicroRNA-34c promotes osteoclast differentiation through targeting LGR4. Gene 610: 1-8.

80. Liao L, Yang X, Su X, Hu C, Zhu X, et al. (2013) Redundant miR-3077-5p and miR-705 mediate the shift of mesenchymal stem cell lineage commitment to adipocyte in osteoporosis bone marrow. Cell Death Dis 4: e600.

81. Wende X, Shifeng W, Haoyi C, Weipeng Z (2016) MicroRNA-133b negatively regulates the proliferation and osteogenic differentiation of bone marrow mesenchymal stem cells. Int J Clin Exp Pathol 9: 12609-12614

82. Cao Z, Moore BT, Wang Y, Peng XH, Lappe JM, et al. (2014) MiR-422a as a potential cellular microRNA biomarker for postmenopausal osteoporosis. PloS One 9:e97098.

83. Lei SF, Papasian CJ, Deng HW (2011) Polymorphisms in predicted mirna binding sites and osteoporosis. J Bone Miner Res 26: 72-78.

84. Qu J, Lu D, Guo H, Wusheng M, Wu G, et al. (2016) MicroRNA-9 regulates osteoblast differentiation and angiogenesis via the AMPK signaling pathway. Mol Cell Biochem 411: 23-33.

85. Dou C, Zhang C, Kang F, Yang X, Jiang H, et al. (2014) MiR-7b directly targets DC-STAMP causing suppression of NFATc1 and c-Fos $s$ ignaling during osteoclast fusion and differentiation. Biochi Biophys Acta 1839: 1084-1096.

86. Wang T, Yin H, Wang J, Li Z, Wei H, et al. (2015) MicroRNA-106b inhibits osteoclastogenesis and osteolysis by targeting RANKL in giant cell tumor of bone. Oncotarget 6: 18980-18996. 